\title{
A ERA DAS UTOPIAS LIGHT: O LEVE COMO IMPERATIVO DA CONDIÇÃO HUMANA
}

\author{
LIPOVETSKY, Gilles. Da leveza:" rumo a uma civilização sem \\ peso. Tradução Idalina Lopes. Barueri: Manole, 2016. 302 p.
}

\author{
Paloma Volski Mariano \\ Universidade Estadual do Centro-Oeste, Paraná, Brasil. \\ Graduada em Filosofia pela Universidade Estadual do Centro-Oeste. Foi pesquisadora bolsista pelo \\ PET/Filosofia em harmonia com duas pesquisas de Iniciação Científica. Atualmente faz pesquisa em \\ Filosofia Contemporânea e Filosofia Política com ênfase em Gilles Lipovetsky. \\ E-mail: palomavolski_m@hotmail.com
}

Em Da leveza: rumo a uma civilização sem peso, Gilles Lipovetsky oferece ao leitor uma profunda e detalhada análise sobre um fator até então deixado de lado para desígnio de pesquisa filosófica, julgado indigno de interesse devido ao seu aspecto fútil, que agora aparece como um assunto sério: a leveza. A abordagem e a discussão da temática evidenciam-se de modo central no comportamento dos indivíduos contemporâneos e também como um dos pontos fulcrais da sociedade de nossos tempos, mostrando-se de grande importância para pesquisas filosóficas em áreas como ética, política e estética. De acordo com Lipovetsky, a leveza sempre esteve presente em nossas sociedades, porém ocupava um papel secundário, manifestando-se, por exemplo, em narrativas mitológicas. Na era hipermoderna, que representa o momento atual, a leveza é um mecanismo de organização social e um princípio que ordena a própria realidade, auxiliada pelas novas tecnologias, mais especificamente em sua ramificação no campo das nanotecnologias.

Nas suas análises em livros anteriores, Gilles Lipovetsky mostrou que a hodierna estrutura social apresenta traços de indivíduos narcísicos, que se preocupam somente consigo mesmos, buscando uma nova referência através do consumo. Dito de outro modo, a sociedade contemporânea é a sociedade do consumo. Tendo em vista a disseminação da leveza por meio de produtos da nanotecnologia, o consumismo está embasado em estratégias características da leveza. No entanto, a leveza não está presente somente em artefatos da tecnociência, mas é uma aspiração exteriorizada nas mais diversas esferas da vida, como a moda, a arte, o lazer, a arquitetura e o design. $O$ autor busca analisar o fenômeno da leveza não fazendo uma condenação ou apologia desta, mas concebendo-a como uma exigência antropológica, um princípio de organização social, um valor tecnológico e estético que em nossos tempos adquire uma importância capital.

O livro é estruturado com uma introdução, que discute o caráter basilar da leveza para a estrutura das sociedades hipermodernas, bem como sua atuação e importância em diversas esferas da vida humana, conforme apresentado no parágrafo anterior e em mais oito capítulos nos quais a obra é dividida.

No primeiro capítulo, Lipovetsky aponta como a leveza está presente na sociedade desde o nascimento do sistema-moda, embora a leveza dos antigos estivesse em um plano secundário, se comparada com a preponderância e o lugar que ocupa na sociedade em nossos tempos. Além disso, o autor aponta 
como a leveza é um aspecto demasiado essencial para a economia do capitalismo de sedução e, em contrapartida, argumenta que o consumo em que a era hipermoderna está pautada se torna um fardo. A leveza é paradoxal: ao passo que ganha espaço como princípio organizador de diversas esferas da vida, traz consigo um fardo que o indivíduo vivencia em momentos do cotidiano. O capitalismo, ao fazer uso da leveza ordenadora, exige que o consumidor pesquise e compare, ou seja, que ele tenha uma escolha esclarecida daquilo que consome, transformando o consumo em objeto de reflexão e preocupação.

O segundo capítulo apresenta a transformação que acontece com o corpo, dado o aumento da obsessão pela saúde e a tirania da magreza, consoante a ascensão do ímpeto de cuidar de si, devido ao culto estético do $\mathrm{Eu}$, com o qual surge uma nova cultura esportiva que busca uma sensação íntima de beleza. A leveza relaciona-se também com esse novo olhar sobre um novo modelo de corpo, que adquire um aspecto democrático, típico das sociedades contemporâneas. Esse culto hipermoderno da leveza consagra uma lógica estritamente autônoma, emancipada de qualquer relação com algo: o corpo é um fim em si, que merece ser cuidado.

No capítulo seguinte, Lipovetsky analisa a leveza nos artefatos técnicos produzidos pela tecnociência, uma vez que a adesão a objetos tecnológicos é um fenômeno específico das sociedades contemporâneas, assim como o aumento da velocidade - tudo sempre vai mais rápido. Estamos imersos em um meio social no qual o princípio de aceleração é comandado pelo próprio princípio da leveza, cujas aplicações manifestam-se nos campos mais variados da vida social e econômica. Os indivíduos hipermodernos estão vivendo em meio a um mundo comandado pelo capitalismo e pela tecnologia, micro e nano, exigindo que o peso dos objetos seja diminuído em busca de uma vida mais leve, aumentando dessa forma a fabricação de micro e nano objetos.

Em seguida, o quarto capítulo retoma uma discussão sobre o fenômeno da moda, que Lipovetsky já havia publicado em seu livro Império do efêmero: a moda e seu destino nas sociedades modernas, concebendo-a como o signo ínfimo da superficialidade, da futilidade e da própria leveza. Hodiernamente a leveza que a moda traz não é mais relegada ao desprezo, mas é ainda considerada um domínio estético inferior. $O$ autor retoma de forma breve a genealogia utilizada em seu livro anterior, salientando o quanto a leveza é parte fundamental desse universo do efêmero e de frivolidades.

o quinto capítulo retrata a leveza na esfera da arte, vínculo que perdura por um longo tempo, exemplificado pelas pinturas com formas e traços delicados e pelas representações com realismo surpreendente, que se assemelham à fotografia. A arte, em todas as suas manifestações, procura expressar um ideal de leveza estética que, mesmo que não seja de forma expressiva, é um ideal explícito como tal. A abordagem de Lipovetsky traz diferentes vanguardas artísticas, mostrando ao leitor como o princípio de leveza sempre esteve presente na arte.

A discussão sobre a leveza trazida no sexto capítulo mostra que esta também aparece como diretriz da arquitetura e do design, traduzindo o avanço da revolução da leveza. Assim como no capítulo anterior, sobre a arte, Lipovetsky faz uma breve e sucinta genealogia da arquitetura, embasando sua argumentação em fatores que aponta ao leitor para demonstrar que a leveza está presente desde o primórdio dos trabalhos arquitetônicos. Assim como os arquitetos, os designers trabalham tendo por pano de fundo o princípio da leveza, ao utilizar materiais leves, 
criando no consumidor um tipo de leveza imaginária que reivindicava a liberdade, o prazer e a ironia. Tanto a arquitetura como o design são áreas que evocam o espetáculo, o lúdico, a sensibilidade e a fluidez.

Posteriormente, o autor traz à tona a questão "somos cool?", com o objetivo de analisar o projeto de tornar a existência mais leve pela melhoria de condições de vida material e no que tange ao aspecto democrático do consumo. Entretanto, sua indagação não é somente em relação ao material, mas também sobre o modo de viver em sociedade, a relação com o passado e tudo aquilo que diz respeito ao coletivo. Trata de temas como a nova fisionomia da família, que é emancipada das restrições da ordem familiar tradicional - a família também adquire o princípio cool. No decorrer desse capítulo, Lipovetsky expõe, de maneira muito perspicaz, os problemas que os novos valores e a falta de referências advindas de um narcisismo desmedido causaram nos indivíduos hipermodernos, bem como o lado negativo da ordem cool.

O oitavo e último capítulo discute como a revolução da leveza transformou a vida privada e a vida pública, apontando que a leveza se reflete até nas atitudes cidadãs do âmbito político - o cenário em que a democracia reside atualmente é de espetáculo. Seu tema central é o princípio de leveza tendo em vista os valores estritamente individualistas da sociedade hipermoderna, a saber, a liberdade, a autonomia e a exaltação da singularidade. A autonomização do indivíduo acompanha a crescente influência do universo da mercadoria, isto é, se o indivíduo hipermoderno é mais livre e autônomo em suas escolhas, ele é mais do que nunca dependente do mercado para satisfazer seus desejos. Portanto, quanto mais a autonomia pessoal aumenta, mais o mercado triunfa e mais o universo comercial traz um peso para nossas vidas.

Em suma, o esclarecimento para questões e debates filosóficos que Gilles Lipovetsky nos traz em Da leveza: rumo a uma civilização sem peso mostra que conduzir a nossa sociedade levando-se em conta o princípio da leveza tanto traz pontos positivos como pontos negativos. Paradoxalmente, quanto mais os indivíduos são guiados por esse princípio, mais fardo possuem para carregar. Na leveza encontramos uma sociedade mais maleável, mais disposta a buscar o prazer e satisfação individual; porém nossa existência se torna desorientada, insegura e fragilizada, rodeada por doenças psíquicas, como a ansiedade e a depressão. Ao mesmo tempo que ganhamos muito em leveza periférica, ganhamos pouco em leveza interna; os indivíduos da era hipermoderna têm dificuldade de viver levemente, renascendo neles o espírito de peso. A mesma civilização que é identificada por ser guiada por princípios da leveza é aquela que representa uma civilização de peso. 